\title{
KAJIAN EKSPERIMENTAL PADA DINDING BATA DI LABORATORIUM DENGAN MENGGUNAKAN METODE DISPLACEMENT CONTROL
}

\author{
Dr. Abdul Hakam ${ }^{1}$, Oscar Fithrah Nur², Rido ${ }^{3}$
}

\begin{abstract}
ABSTRAK
Gempa bumi yang melanda Sumatera Barat, 6 Maret 2007 dan 30 September 2009 merupakan salah satu bentuk pengulangan gempa di masa lalu dan merupakan petunjuk yang jelas bahwa belum banyak yang dilakukan berkaitan dengan rumah sederhana. Berdasarkan temuan di hampir semua gempa yang menimpa daerah Sumatera Barat tersebut, bangunan yang mengalami kerusakan dan roboh adalah rumah sederhana yang dibangun secara spontan (non engineered building), dimana bangunan yang dibangun berdasarkan pengalaman praktis dan kekuatan strukturnya tidak dihitung. Salah satu bentuk kesalahan konstruksi pada bangunan yang terdapat di Sumatera Barat ini adalah bangunan tidak memiliki elemen struktur berupa kolom dan fungsi kolom digantikan langsung oleh susunan batu bata pada dinding. Bentuk kerusakan pada bangunan yang terjadi akibat gempa adalah terjadi retak dan pemisahan pada dinding bata. Kebanyakan bangunan yang ada dibuat pada masa yang tidak mengingatkan orang akan bahaya gempa bumi. Untuk gempa yang tidak terlalu besar, bangunan kemungkinan akan tetap berdiri dengan sedikit kerusakan. Namun untuk mengantisipasi gempa bumi yang kuat dan mengurangi dampak buruk yang ditimbulkan, maka bangunan rumah berdinding bata tersebut harus dibangun sesuai ketentuan konstruksi bangunan tahan gempa dengan memberikan perkuatan pada bagian-bagian tertentu seperti pemasangan jaring kawat pada dinding sebagai salah satu perkuatan. Oleh karena itu untuk mengetahui berapa besar pengaruh dari pasangan jaring kawat pada dinding bata ini, maka dilakukanlah penelitian terhadap dinding yang tidak memiliki kolom. Pengujian ini dilakukan terhadap 4 benda uji yaitu benda uji tanpa plester yang menggunakan perkuatan dan tidak menggunakan perkuatan, dan benda uji plester yang menggunakan perkuatan dan tidak menggunakan perkuatan. Pola keretakan yang terjadi pada semua benda uji berupa keretakan vertikal. Keretakan terdapat pada ikatan pasangan batu bata (plester) dan pecahnya batu bata. Penambahan plester pada dinding bata dapat meningkatkan nilai beban maksimum yang mampu diterima oleh dinding bata secara signifikan. Perkuatan kawat dapat meminimalkan terjadinya keruntuhan secara tiba-tiba dan menambah daya ikat pasangan batu bata pada dinding
\end{abstract}

Kata Kunci : gempa, jaring kawat, rumah sederhana.

\section{PENDAHULUAN}

Gempa bumi yang akhir-akhir ini terjadi di Indonesia banyak menyisakan sorotan tentang kegagalan kostruksi yang ditujukan pada pakar konstruksi di Indonesia. Telah banyak tuntutan untuk merancang suatu konstruksi yang tahan terhadap gempa baik dari golongan awam sampai pada golongan masyarakat. Untuk mendapatkan struktur yang kuat terhadap pengaruh gempa, perlu dirancang struktur yang kaku pada saat terjadi gempa kuat. Sehingga pada saat terjadi gempa kuat, struktur mempunyai kemampuan untuk menghalangi deformasi yang besar tanpa mengakibatkan keruntuhan.

Fakta yang bisa dilihat dari pasca gempa adalah bangunan rusak dan roboh. Komponen yang sangat vital adalah komponen dinding bata. Hal-hal yang menyebabkan kerusakan dinding bata ini adalah:

\footnotetext{
${ }^{1}$ Dosen Jurusan Teknik Sipil Universitas Andalas, ahakam2008@yahoo.com

${ }^{2}$ Dosen Jurusan Teknik Sipil Universitas Andalas, oscar@ft.unand.ac.id

${ }^{3}$ Ex Mahasiswa Jurusan Teknik Sipil Universitas Andalas
} 
1. Tidak mengikuti kaedah rumah aman gempa

2. Material yang tidak memenuhi standar

a. Bata yang sekarang banyak diproduksi mempunyai ukuran yang lebih kecil. Bata ideal mempunyai ukuran $6 \times 12 \times 24 \mathrm{~cm}$.

b. Mortar, plesteran, dan acian dengan komposisi yang tidak sesuai.

3. Prosedur kerja yang tidak mengikuti aturan.

Tujuan dari penelitian ini adalah untuk mengetahui perilaku dinding bata pada saat diuji dengan menggunakan beban siklik (beban bolak-balik), mengetahui pola keretakan, dan perbandingan perpindahan dengan beban. Manfaat yang hendak dicapai adalah mengetahui aturan dan prosedur yang baik untuk membuat dinding bata tahan gempa. Dapat menambah referensi tentang perencanaan dan pembangunan rumah tahan gempa. Memberikan pemahaman tentang prinsipprinsip keretakan pada dinding bata sehingga dapat mengantisipasi keretakan pada waktu gaya gempa bekerja, dimana bisa digunakan sebagai acuan selanjutnya.

Ruang lingkup pembahasan makalah ini meliputi:

1. Model dinding bata yang dibahas :

a. dinding bata tanpa plester

b. dinding bata dengan plester

c. dinding bata tanpa plester dilapisi jaring kawat bukaan 1 inci dan paku

d. dinding bata dengan plester dilapisi jaring kawat bukaan 1 inci dan paku

2. Pembebanan berupa beban siklik (beban bolak-balik).

3. Penelitian ini meliputi perbandingan terhadap beban maksimum yang dapat ditanggung oleh model dinding bata tersebut yang dilakukan di laboratorium dengan perpindahan yang terjadi (grafik load vs displacement).

\section{TINJAUAN PUSTAKA}

\subsection{Umum}

Gempa Bumi didefenisikan sebagai kejutan atau sentakan yang terjadi di dalam bumi yang getarannya dapat dirasakan di permukaaan bumi. Gempa disebabkan oleh peningkatan aktivitas geologi yang terjadi di dalam bumi, seperti terjadinya pergeseran-pergeseran antar lempeng benua pada daerah batas lempeng, meningkatnya suhu yang dapat menimbulkan penumpukan energi dalam waktu yang lama, sampai akhirnya terlepas dan menyebabkan getaran dalam tanah.

Indonesia merupakan daerah pertemuan 3 lempeng tektonik besar, yaitu lempeng Indo-Australia, Eurasia dan lempeng Pasifik. Lempeng Indo-Australia bertabrakan dengan lempeng Eurasia di lepas pantai Sumatera, Jawa dan Nusatenggara, sedangkan dengan pasifik berada di utara Irian dan Maluku Utara. Di sekitar lokasi pertemuan lempeng ini akumulasi energi tabrakan terkumpul sampai suatu titik dimana lapisan bumi tidak sanggup menahan tumpukan energi sehingga lepas berupa gempa bumi. Pelepasan energi sesaat ini menimbulkan berbagai dampak terhadap bangunan (keretakan atau runtuh).

Tipe batas lempeng di Indonesia merupakan tipe subduksi. Daerah-daerah di sekitar batas lempeng ini merupakan daerah-daerah yang sering terjadi gempa bumi.

\subsection{Rumah Sederhana (Non-Engineered House)}

Pengertian bangunan non-engineered adalah bangunan rumah tinggal dan bangunan komersil sampai 2 lantai yang dibangun oleh pemilik, menggunakan tukang setempat, menggunakan bahan bangunan yang didapat setempat, tanpa bantuan arsitek maupun ahli struktur (Boen, 2007).

\section{6 | JURNAL REKAYASA SIPIL}




\section{Dr. Abdul Hakam, Oscar Fithrah Nur, Ridho}

Pengerjaan bangunan yang hanya melibatkan pekerja atau tukang setempat membuat kualitas pekerjaan yang dihasilkan rendah. Selain itu biasanya tukang hanya membangun tanpa memperhatikan syarat atau pedoman dalam membangun bangunan sederhana, terutama rumah sederhana (non-engineered house). Pengerjaan hanya didasarkan pada perkiraan atau pengalaman membangun sebelumnya. Rumah sederhana merupakan bangunan dengan sistim dinding pemikul beban, dan analisanya harus sebagai bangunan dinding pemikul. Di banyak daerah, ditemukan bahwa banyak para ahli struktur kurang memahami masalah dinding pemikul ini dan banyak yang membuat analisa dengan menghitung rangka kolom praktis dan balok keliling saja dan dindingnya tidak diperhitungkan. Dengan sendirinya prilaku suatu rangka dengan dinding akan sangat berbeda kalau digoncang gempa dibandingkan dengan prilaku rangka saja.

\subsection{Prinsip Rumah Aman Gempa}

Bangunan yang didesain aman gempa pada prinsipnya harus menjamin keamanan dan kenyaman penggunaan bangunan. Untuk menghasilkan bangunan yang berkualitas harus didukung oleh penggunaan material yang bermutu, tenaga kerja yang terampil dan teknik pengerjaan yang tepat sesuai ketentuan pendirian bangunan dan fungsi bangunan.

Disain struktur pada umumnya berdasarkan atas suatu standard atau kode bangunan, yang menyatakan bahwa bangunan boleh rusak berat (suffer mayor damage) tetapi tidak boleh runtuh (should not collapse) akibat beban gempa rencana maksimum. Sedangkan untuk jenis beban yang lainnya, bangunan didisain tidak boleh rusak sama sekali akibat beban kerja (beban angin dan beban gravitasi). Mendisain struktur yang tahan terhadap beban gempa lebih sukar dibandingkan dengan beban lainnya. Hal ini disebabkan karena adanya faktor ketidakpastian dan juga karena konsep dasar dari langkah disain tahan gempa berbeda dengan konsep disain terhadap beban lainnya.

\subsection{Kerusakan Dinding Bata Akibat Gempa}

Berdasarkan hasil pengamatan terhadap kerusakan bangunan akibat gempa, kerusakan tipikal yang terjadi adalah dinding cenderung untuk berpisah, dinding cenderung untuk roboh sebagian, dinding mengalami retak diagonal dan terjadi puntir pada bangunan yang tidak simetris. Hal ini terjadi sebagian besar dikarenakan oleh faktor seperti kurang kuatnya ikatan antara pasangan bata. Gambar 1. menunjukkan kerusakan dinding yang disebabkan oleh gempa bumi:
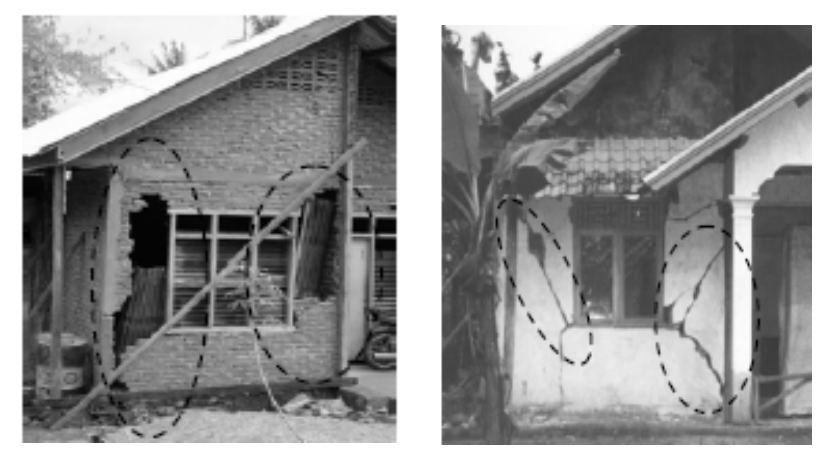

\section{Gambar 1. Kerusakan Dinding Akibat Beberapa Gempa di Indonesia}

Masyarakat sekarang cenderung mengabaikan cara pemasangan dinding bata yang tepat. Pola susunan bata misalnya sangat beragam ditemukan dimasyarakat, namun ketika hal ini dipertanyakan tidak ada dalil yang tepat untuk memastikan pola susunan bata tersebut adalah baik, selain itu tebalnya spesi antar bata dan kualitas mortar sama sekali tidak diperhatikan dan selalu 
bersifat perkiraan. Sehingga pada saat terjadi gempa banyak sekali terjadi keruntuhan pada dinding dengan pola keruntuhan yang berbeda-beda.

\section{METODOLOGI}

\subsection{Program Kerja}

Penelitian dilakukan menurut tahapan berikut:

a. Tahapan Analisis Tahapan Persiapan

Merupakan tahapan awal dalam melakukan penelitian untuk menentukan item-item pekerjaan yang akan dilakukan dan mempersiapan alat dan bahan percobaan penelitian di laboraorium.

b. Tahapan Studi Pustaka

Merupakan studi penulisan yang bersumber dari buku-buku dan berbagai sumber lainnya untuk menambah pemahaman dan mencari sumber yang tepat dalam pelaksanaan percobaan dari respon model dinding yang dilakukan di laboratorium.

c. Tahapan Percobaan Penelitian

Merupakan pengambilan data yaitu berupa data yang diperoleh dari hasil percobaan penelitian yang dilakukan di laboratorium.

d. Tahapan Analisis

Menganalisa data yang diperoleh dari hasil percobaan penelitian yang outputnya untuk mendapatkan hasil yang terbaik perbandingan beban maksimum yang dapat dipikul oleh model dinding sehingga didapat keandalan dari model dinding yang diuji di laboratorium.

\subsection{Benda Uji}

Benda uji dinding bata sebanyak 4 buah dengan masing-masing variasi.

Data dinding bata yang digunakan dalam percobaan :

a) Batu bata memiliki dimensi $(20 \times 10 \times 5) \mathrm{cm}$

b) Campuran plesteran dan spesi menggunakan perbandingan campuran 1:4

c) Kawat bukaan 1 inci dengan diameter kawat $0.75 \mathrm{~mm}$

d) Paku ukuran 1,5 inci

\subsection{Peralatan Pengujian Dinding Bata}

Alat pengujian dinding bata terdiri dari :

a. Besi pengikat dinding bata (Gambar 2)

Digunakan untuk tempat mengikat dinding bata yang akan diuji di laboratorium. Dinding bata diikatkan ke lantai.

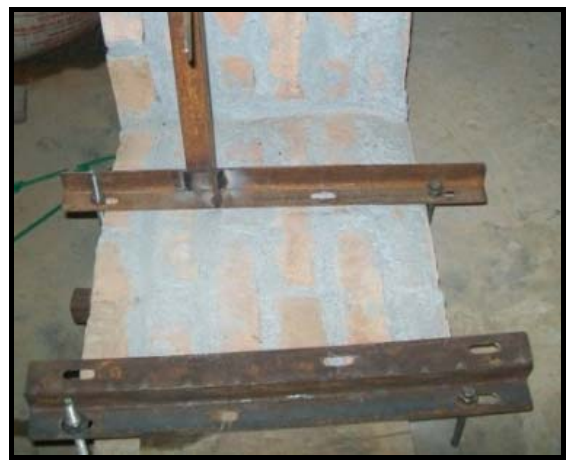

\section{Gambar 2. Besi Pengikat Dinding Bata}

\section{J JURAL REKAYASA SIPIL}


b. Alat pembebanan (Gambar 3.)

Untuk memberikan beban dorong pada portal. Alat pembebanan ini dilengkapi dengan dial untuk membaca beban.

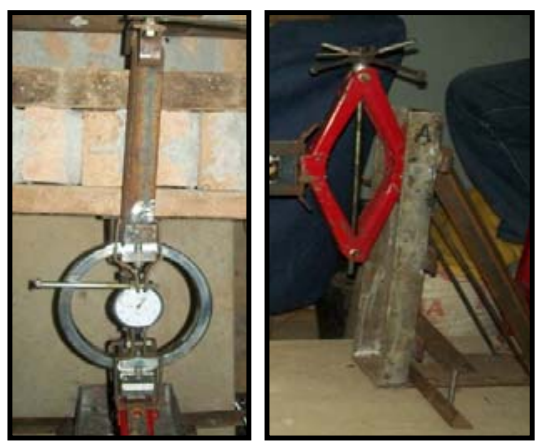

Gambar 3. Alat Pembebanan

c. Kamera digital dan handycam

Berguna untuk dokumentasi, mengambil vidio dan gambar waktu pengujian.

d. Dial (Gambar 4.)

Untuk membaca perpindahan dan beban pada portal. Dial perpindahan yang digunakan hanya mampu membaca perpindahan maksimum $7 \mathrm{~cm}$.

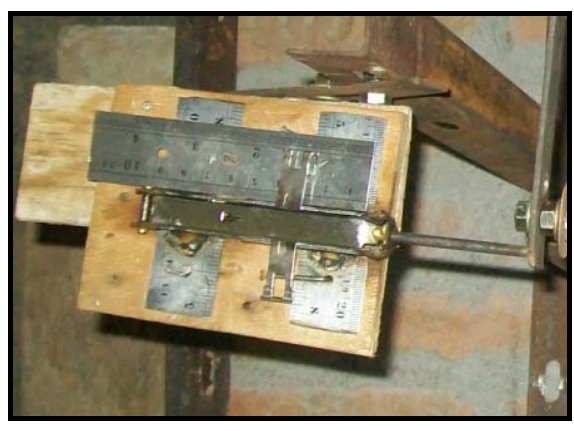

Gambar 4. Dial Perpindahan

\subsection{Pemodelan Alat dan Prosedur Percobaan}

\subsubsection{Permodelan Alat}

Percobaan di laboratorium dilakukan dengan membuat suatu pemodelan alat sebagai berikut (Gambar 5.):

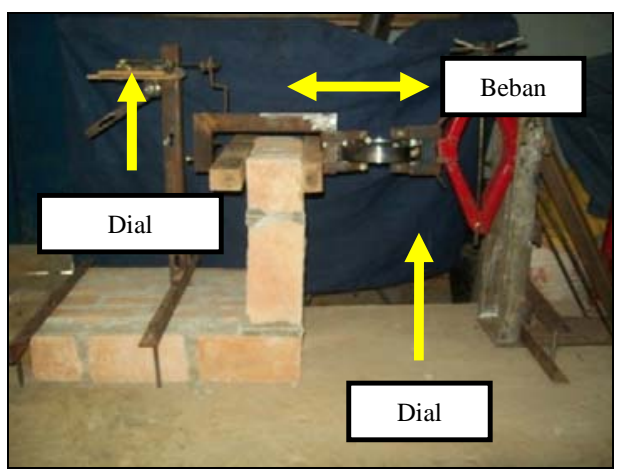

Gambar 5. Pemodelan di laboratorium 


\subsubsection{Prosedur Percobaan}

1. Pasang dinding bata pada perletakannya dan atur posisi letak dinding bata.

2. Setelah itu pasang alat pembebanan yang dilengkapi dengan dial beban.

3. Pasang dial perpindahan.

4. Siapkan data form untuk mencatat berapa besar perpindahan dan beban dorong yang diberikan.

5. Pastikan handycam dan kamera digital sudah siap untuk mengambil dokumentasi.

6. Kemudian lakukan pengujian dengan memberikan beban. Hal ini dilakukan berulang-ulang sampai dinding bata runtuh.

\section{HASIL DAN PEMBAHASAN}

Benda uji telah selesai dibuat sesuai dengan prosedur dan rencana kerja yang ada. Benda uji yang dibuat tersebut ada 4 buah yaitu yang polos tidak menggunakan perkuatan dan menggunakan perkuatan, dan yang diplester tidak menggunakan perkuatan dan menggunakan perkuatan Benda uji tersebut dapat dilihat pada Gambar $\mathbf{6}$ dan $\mathbf{7}$.

Benda uji tersebutlah yang nantinya akan dilakukan pengujian untuk mengetahui bagaimana pengaruh pemasangan dari perkuatan itu sendiri.

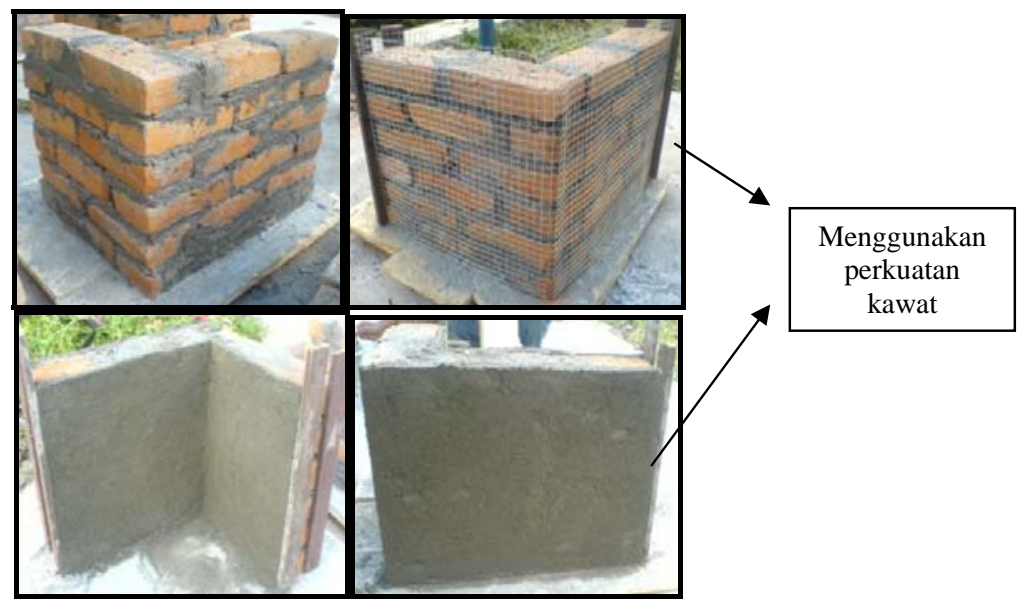

Gambar 6. Benda Uji Dinding Bata

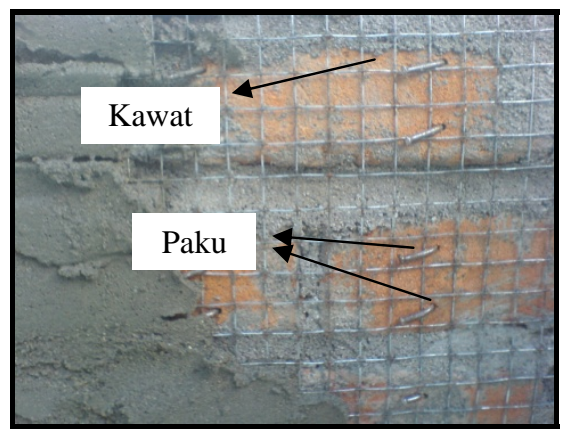

Gambar 7. Detail Pemasangan Perkuatan 
Dr. Abdul Hakam, Oscar Fithrah Nur, Ridho

\subsection{Dinding Bata Polos (Tipe 1)}

Gambar 8. Menunjukkan benda uji sebelum menerima beban

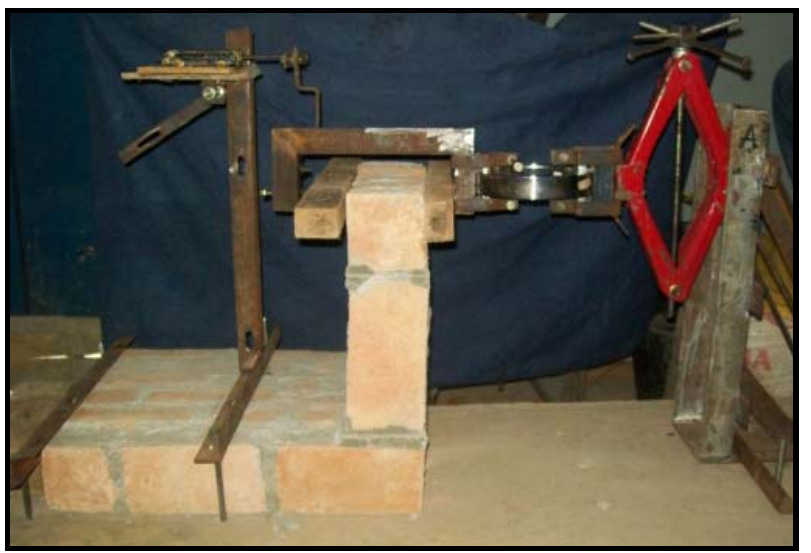

Gambar 8. Benda Uji Sebelum Menerima Beban

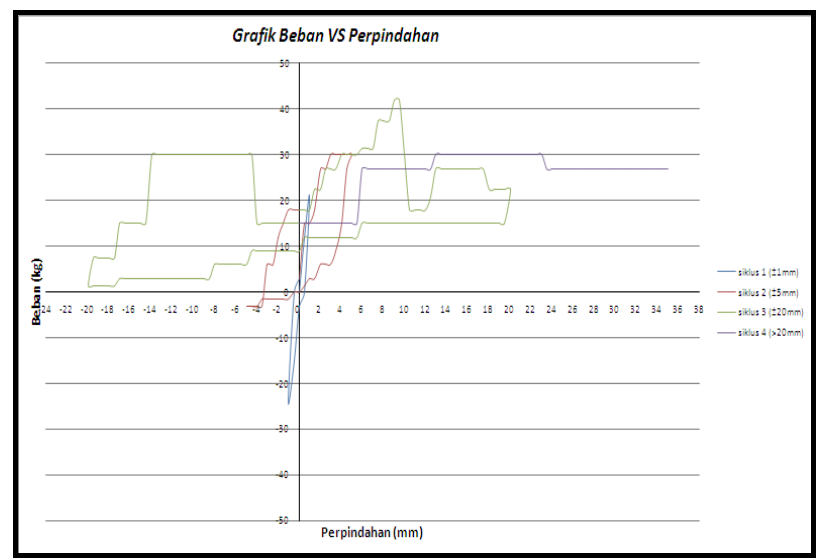

Gambar 9. Kurva Hysteresis Loop Beban-Perpindahan

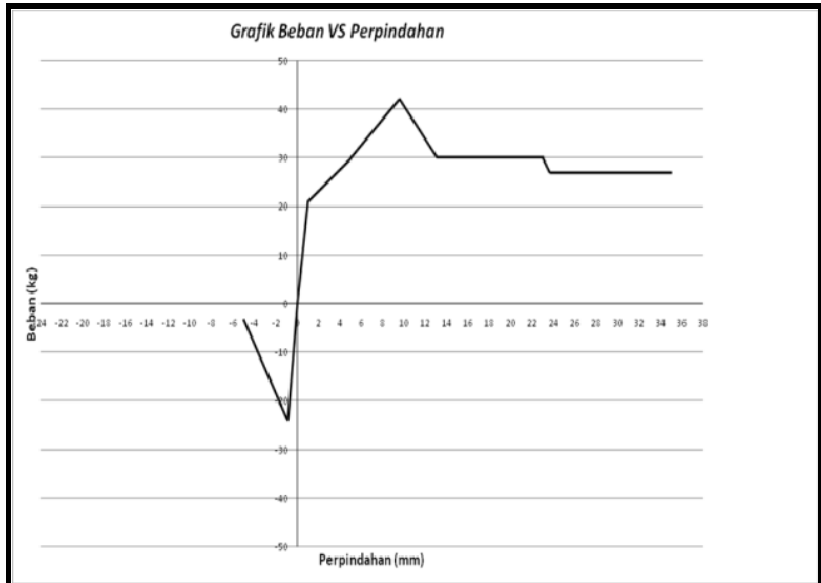

Gambar 10. Kurva Keruntuhan Dinding Bata Polos 


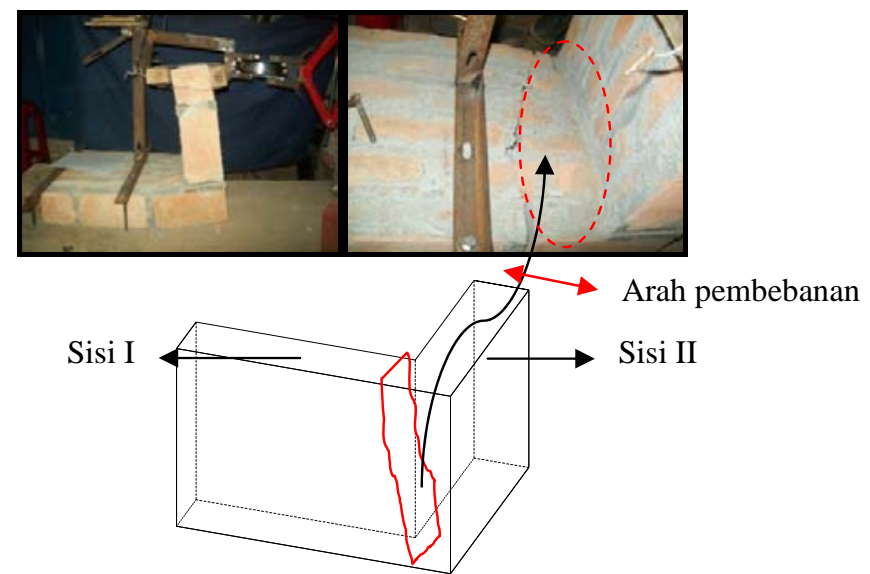

Gambar 11. Benda Uji Setelah Menerima Beban

Dari Gambar 9 dan 10. yang dihasilkan dari percobaan dinding polos yang tidak menggunakan perkuatan mendapatkan beban maksimum sebesar $42 \mathrm{~kg}$ dimana benda uji tersebut telah mencapai batas ultimate dengan perpindahan yang terjadi $9 \mathrm{~mm}$. Pola keretakan terjadi secara vertikal, dapat dilihat pada Gambar 11. dimana retak terjadi karena kegagalan bata dan kegagalan ikatan pasangan batu bata. Keretakan terjadi hanya pada satu sisi dinding saja.

\subsection{Dinding Bata Polos Dengan Perkuatan (Tipe 2)}

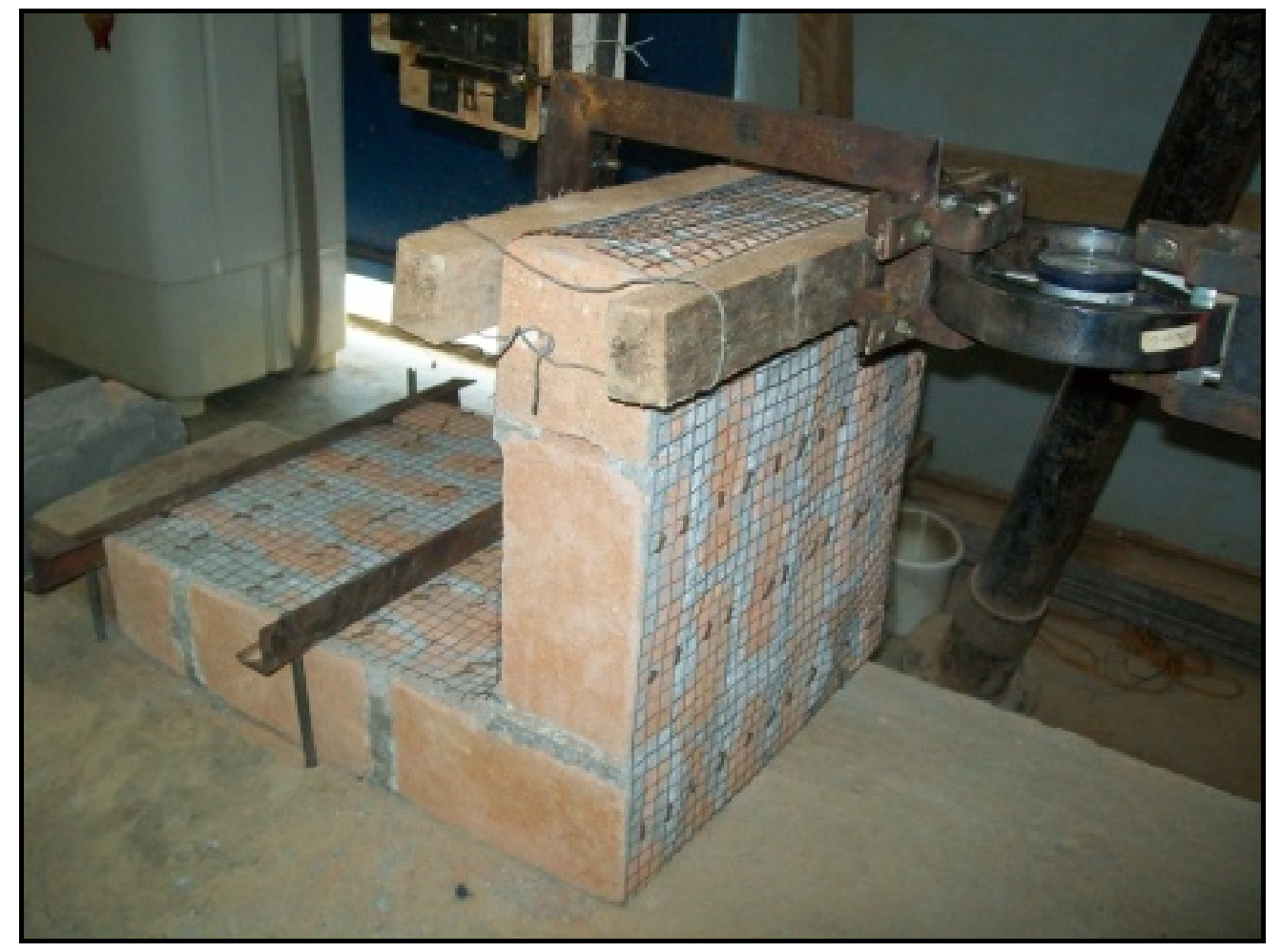

Gambar 12. Benda Uji Sebelum Menerima Beban

\section{J JURAL REKAYASA SIPIL}




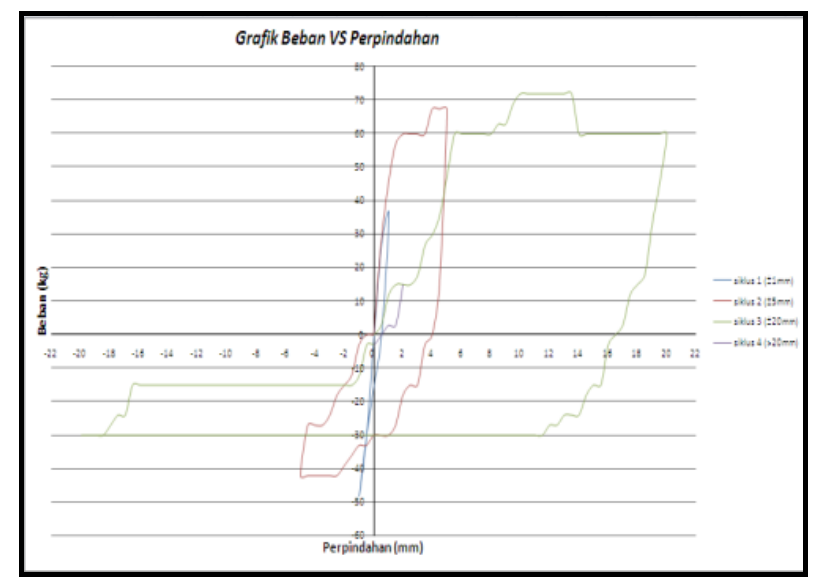

\section{Gambar 13. Kurva Hysteresis Loop Beban-Perpindahan}

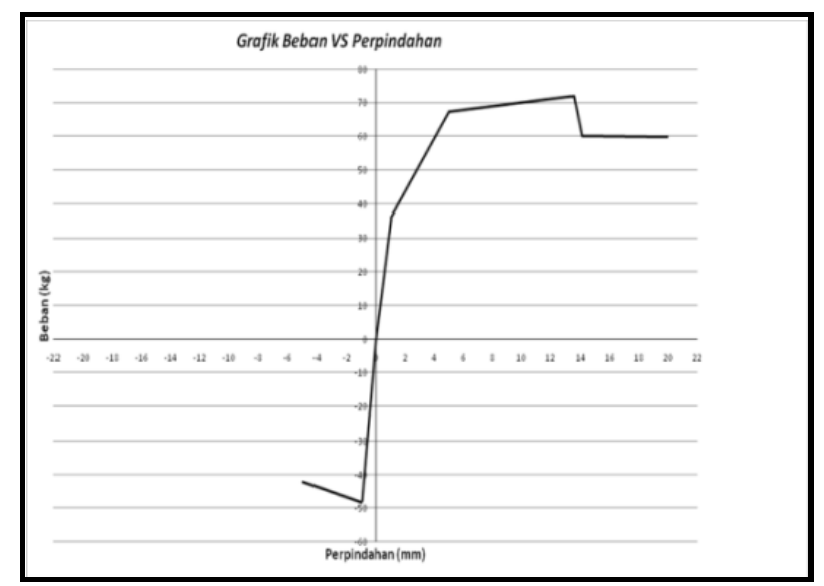

\section{Gambar 14. Kurva Keruntuhan Dinding Bata Polos Dengan Perkuatan}

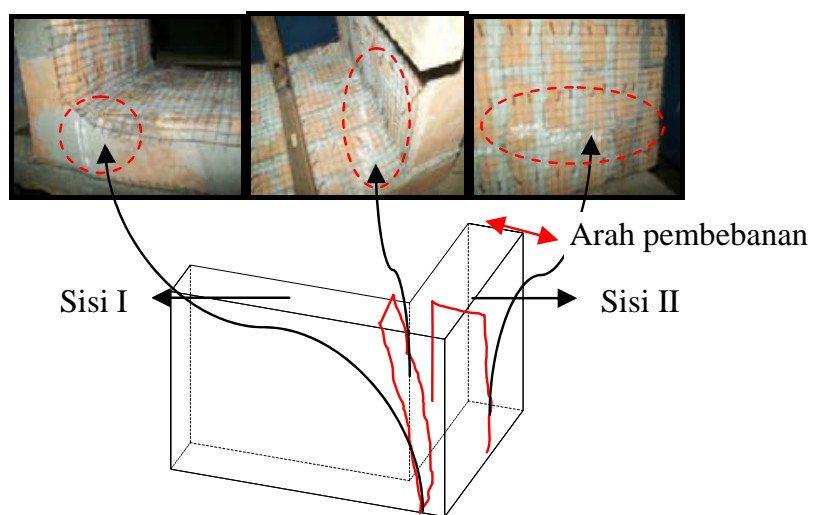

Gambar 15. Benda Uji Setelah Menerima Beban

Gambar 12 - 14. menunjukkan hasil dari percobaan dinding polos yang menggunakan perkuatan (kawat) mendapatkan beban maksimum sebesar $72 \mathrm{~kg}$, dimana benda uji tersebut telah mencapai batas ultimate dengan perpindahan yang terjadi $13,5 \mathrm{~mm}$. Saat ini juga ditandai terpisahnya antara 
dinding bata dan spesi, dan pecahnya batu bata seperti yang terlihat pada Gambar 15. pola retak vertikal. Keretakan terjadi pada kedua sisi dinding bata.

\subsection{Dinding Bata Plester (Tipe 3)}

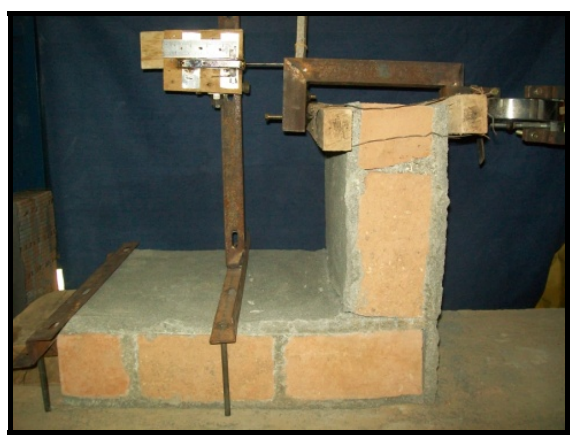

Gambar 16. Benda Uji Sebelum Menerima Beban

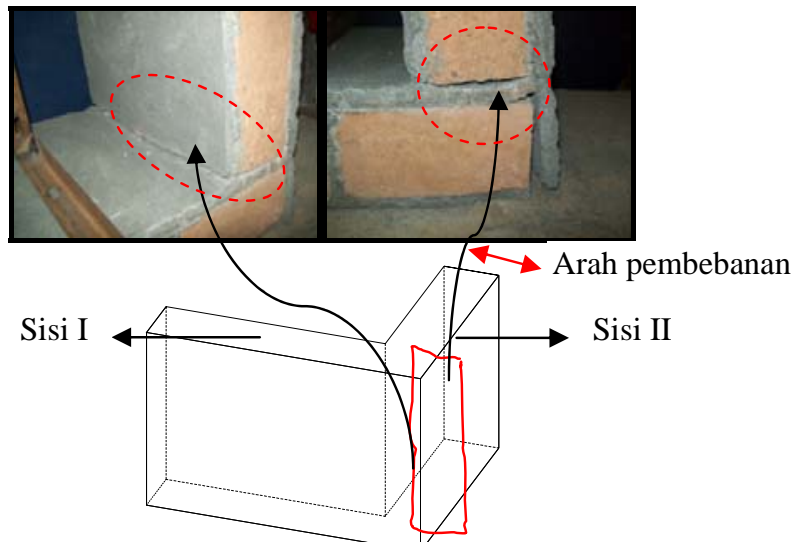

Gambar 17. Benda Uji Setelah Menerima Beban

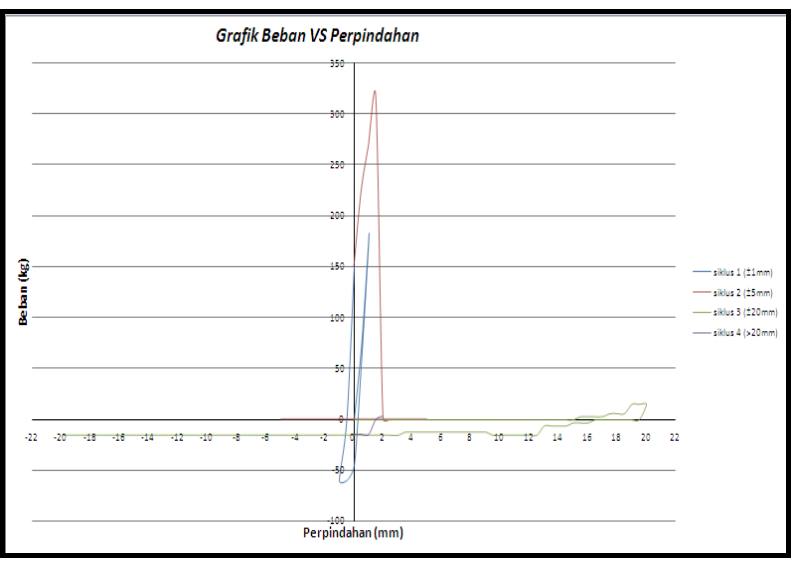

Gambar 18. Kurva Hysteresis Loop Beban-Perpindahan 


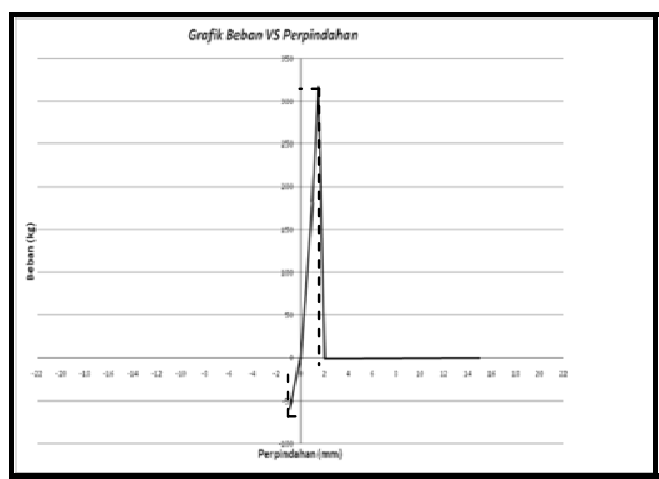

\section{Gambar 19 Kurva Keruntuhan Dinding Bata Plester}

Dari Gambar 18 - 19. terlihat bahwa dinding plester yang tidak menggunakan perkuatan mendapatkan beban maksimum sebesar $318 \mathrm{~kg}$ dimana benda uji tersebut telah mencapai batas ultimate dengan perpindahan yang terjadi $1,5 \mathrm{~mm}$. Pola keretakan vertikal dapat dilihat pada Gambar 16 - 17. dimana retak terjadi karena kegagalan bata, kegagalan ikatan pasangan batu bata dan lepasnya ikatan plester pada batu bata. Keretakan terjadi hanya pada satu sisi dinding saja.

\subsection{Dinding Bata Plester Dengan Perkuatan (Tipe 4)}

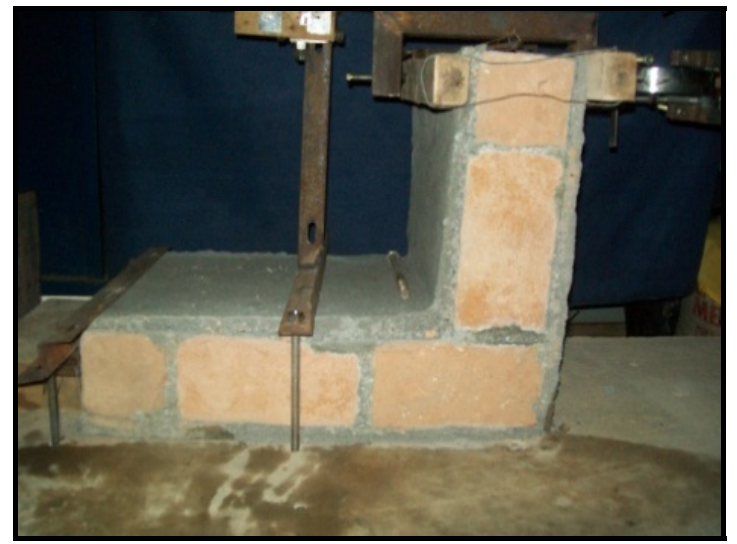

\section{Gambar 18. Benda Uji Sebelum Menerima Beban}

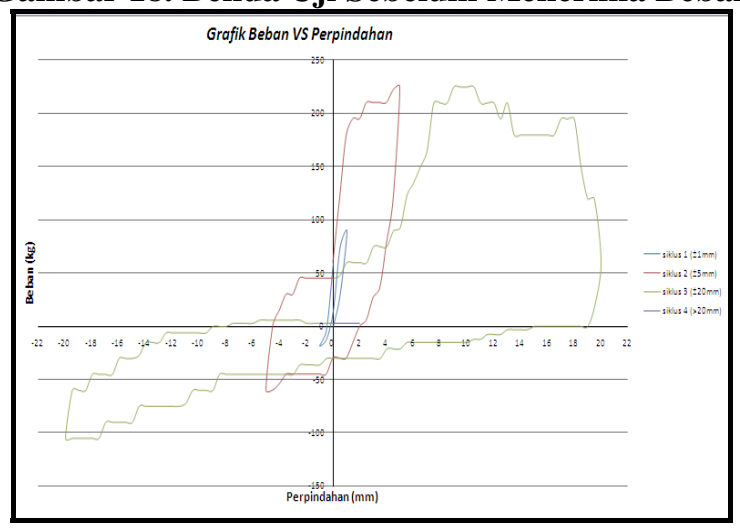

Gambar 19. Kurva Hysteresis Loop Beban-Perpindahan 


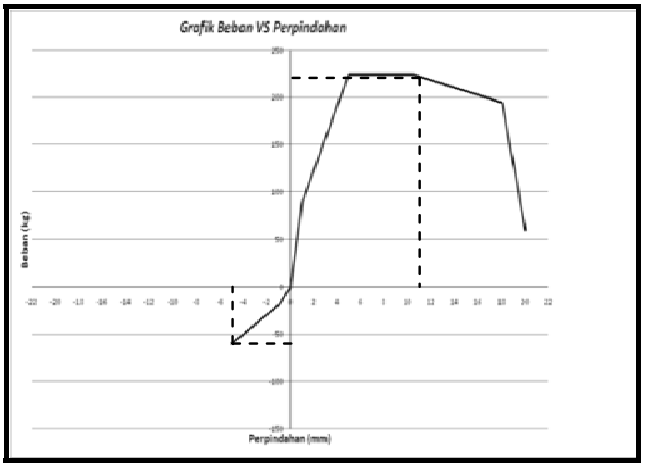

Gambar 20. Kurva Keruntuhan Dinding Bata Plester Dengan Perkuatan

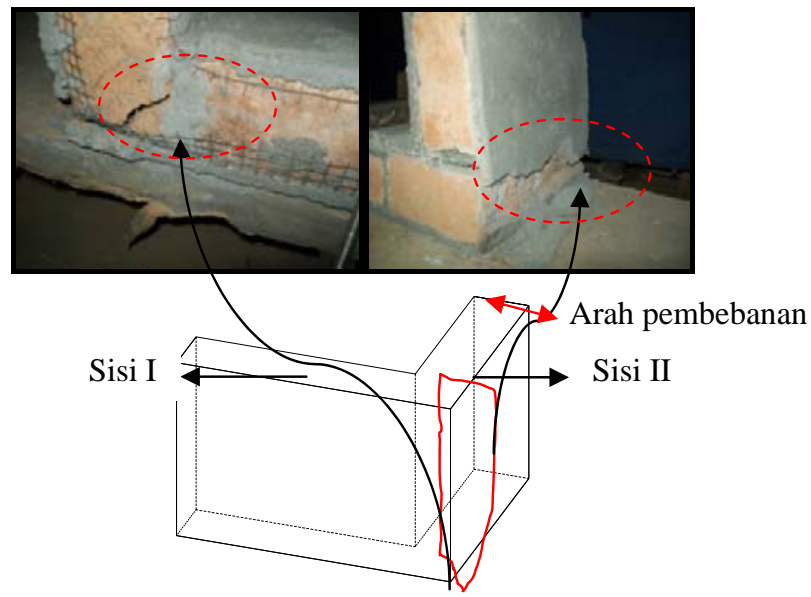

\section{Gambar 21. Benda Uji Setelah Menerima Beban}

Dari Gambar 18-20. diperoleh dinding polos yang menggunakan perkuatan (kawat) mendapatkan beban maksimum sebesar $225 \mathrm{~kg}$ dimana benda uji tersebut telah mencapai batas ultimate dengan perpindahan yang terjadi $10,5 \mathrm{~mm}$. Saat ini juga ditandai terpisahnya antara dinding bata dan spesi, dan pecahnya batu bata seperti yang terlihat pada Gambar 21. Lapisan plester juga mengalami keretakan dan terlepas dari dinding bata. Pola retak vertikal, keretakan terjadi sebagian besar pada sisi II dan sebagian kecil pada sisi I dinding bata.

\subsection{Perbandingan Dinding Bata Tipe 1, Tipe 2, Tipe 3, Tipe 4}

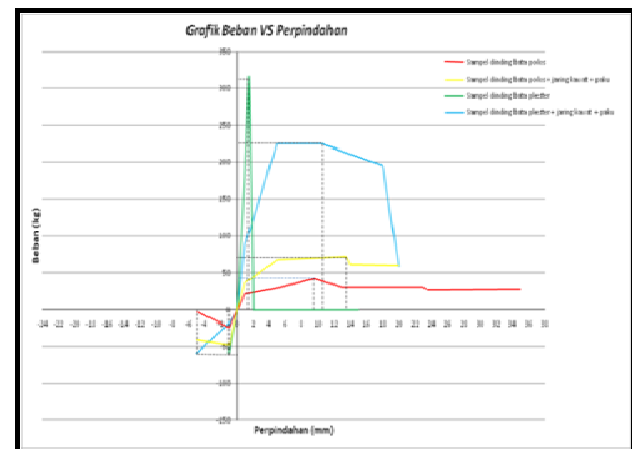

Gambar 22. Perbandingan Kurva Keruntuhan Masing-Masing Benda Uji

\section{6 | JURNAL REKAYASA SIPIL}




\section{Dr. Abdul Hakam, Oscar Fithrah Nur, Ridho}

Retakan diawali pada ikatan pasangan batu bata (spesi) yang kemudian diikuti dengan kegagalan dari batu bata, retakan terus terjadi pada spesi dan batu bata yang lain sehingga membentuk garis tegak lurus (vertikal). Pola retak vertikal terjadi pada masing-masing benda uji.

Pada Gambar 22. menunjukkan perbedaaan beban maksimum yang dapat diterima oleh dinding bata dengan perpindahan yang terjadi. Penambahan plester dapat menambah kemampuan dinding menerima beban maksimum yang cukup signifikan bila dibandingkan dengan sampel tanpa plester. Perkuatan (kawat) dapat meningkatkan beban yang diterima oleh dinding.

Plester dapat menambah ikatan pasangan batu bata sehingga beban maksimum yang dapat diterima dinding bata meningkat. Pada sampel tipe 3 mengalami keruntuhan secara tiba-tiba. Hal ini dapat terjadi karena reaksi perlawanan terhadap beban yang diterima dinding hingga batas maksimumnya dan mengalami keruntuhan bersamaan dengan pecahnya plester dan spesi sehingga dinding mengalami keruntuhan.

Perkuatan pada sampel tipe 4 dapat meminimalkan kemungkinan terjadinya keruntuhan secara tibatiba. Bukaan pada jaring kawat dapat menambah daya ikat plester pada bata. Jaring kawat yang dipakukan pada batu bata akan mengikat bata setelah terjadinya keruntuhan dimana ikatan pasangan batu bata telah hilang. Dari data dan pengamatan hasil percobaan, perkuatan yang diberikan berguna untuk menambah daya ikat pasangan batu bata. Perkuatan ini juga dapat meminimalkan kemungkinan terjadinya keruntuhan tiba-tiba.

\section{KESIMPULAN}

Berdasarkan pengujian yang telah dilakukan, maka dapat disimpulkan bahwa:

1. Pola keretakan yang terjadi pada semua benda uji berupa keretakan vertikal. Keretakan terdapat pada ikatan pasangan batu bata (plester) dan pecahnya batu bata.

2. Penambahan plester pada dinding bata dapat meningkatkan nilai beban maksimum yang mampu diterima oleh dinding bata secara signifikan.

3. Perkuatan kawat dapat meminimalkan terjadinya keruntuhan secara tiba-tiba dan menambah daya ikat pasangan batu bata pada dinding.

\section{DAFTAR KEPUSTAKAAN}

Boen T., (2007), “Engineering Non Engineered Buildings, From Non Engineered to 3D Non Linear Analysis, Perfomance Based Design”, Seminar dan Pameran HAKI 2007. 
Kajian Eksperimental Pada Dinding Bata Di Laboratorium Dengan Menggunakan Metode Displacement Control

\section{J URNAL REKAYASA SIPIL}

